\title{
Development of Performance Appraisal System for Local School Teachers in Thailand
}

\author{
Suphawadee Uttaramart ${ }^{1}$, Kowat Tesaputa ${ }^{1}$ \& Anan Sri-am-pai ${ }^{1}$ \\ ${ }^{1}$ Faculty of Education, Mahasarakham University, Thailand \\ Correspondence: Suphawadee Uttaramart, Faculty of Education, Mahasarakham University, Muang \\ Mahasarakham District, Mahasarakham Province 44150, Thailand. Tel: 66-089-841-3521. E-mail: \\ Su.uttaramart@gmail.com
}

Received: July 16, 2015 Accepted: August 27, 2015 Online Published: October 28, 2015

doi:10.5539/ies.v8n11p228 URL: http://dx.doi.org/10.5539/ies.v8n11p228

\begin{abstract}
The objectives of this research were: 1) to study current situation and problem in the performance appraisal system of secondary school teachers, under jurisdiction of the Local Administrative Organization (LAO), 2) to develop the performance appraisal system to apply with the LAO school teachers, and 3) to evaluate the application from the performance appraisal system by using research and development process. The researcher intended to study the current situation and problem of appraisal system in work practice of secondary school teachers. The research was based on the appraisal system, system development, evaluation of performace, factors in performance appraisal system, the LAO educational administration, and the Good Governance principle. The samples were 758 school directors, vice-directors, and division/department chairs from the secondary schools in Thailand. Research instruments were semi-structure interview, rating scale questionnaires, and open-ended questions. Research finding revealed that ethical values were the highest rank in content of performance appraisal while learning management ranked the lowest. Discussion aspects were included current situation, performance appraisal system, application of the system, and satisfaction to performance appraisal system.
\end{abstract}

Keywords: system development, performance appraisal system, work performance

\section{Introduction}

In Thailand, school administration is mainly responsible by the Ministry of Education which centrally managed under its procedures and policy. Fortunately, the National Education Act B.E 2542 (1999) allowed the Local Administration Organization (LAO) to administer local schools by its jurisdiction. Each LAO can adopt existing schools into its administration in order to decentralize the chain of command to local administration. The standard of education yet has to be conformed to the main national curriculum but appraisal system and personnel administration can be varied by certain circumstances. Appraisal system is the main tool to use in salary raise, rank promotion, and annual bonus. It is used as the benchmark for performance operation compared to the job description. Appraisal procedure for the government officials in Thailand is done twice a year. Each of them has to meet the criteria on effectiveness of the duty and efficiency of the person.

\subsection{Introduction to the Problem}

Performance appraisal for school under the LAO jurisdiction has been conducted according to the procedure guide of the Office of Civil Service system. However, many unclear appraisal procedures allow injustice evaluation. It was reported that some administrators lacked of complete comprehension in appraisal system and absence of the Good Governance principles (Wongprakan, 2008). Problems in performance appraisal directly affected human resource development and educational training. Most of the time, performance appraisal was used in the salary raise and rank promotion rather than using it as an instrument for staff development. This problem was related to the application of how to use appraisal system for professional development. In some LAO schools, it was found that appraisal was administered salary raising purpose but lacked of evaluation in performance as an instrument in evaluating the staffs' knowledge and competency in work. Appraisal is an indicator of relationship between the knowledge of the staff and their competency to comply with the expectation of organization (Maharatsakul, 2002). Problem in appraisal system should not be neglected. In the advanced organization with systematic administration, the performance appraisal was the most important administrative instrument as a positive stimulating force of work practice (Noe et al., 2003). Result of appraisal 
can be applied for multi-purpose besides salary raising such as planning for future work appraisal, determination of necessity in training and developing the staffs, and potentiality for being on promotion (Peck, 1984). In the future, the LAO can avoid the problem of appraisal system by raising awareness on potentiality of the system for overall administrative purposes.

In Thailand's government organizational context, the performance appraisal was specified by The Office of Civil Service as the following procedures: 1) the practitioners had to pass the Government Official Appraisal System twice a year, the First Round (1st October-31st March of the following year), the Second Round (1st April-30th September). In each round, the practitioners had to make an agreement of the performance with the committee. They would be appraised by comparing their actual performance with specific goals. Results would be concluded in different scores at the end of the round, 2) the Government Official Performance Appraisal System would be considered from at least two factors including effectiveness of the work and efficiency of the person. In addition, third factor appraisal might be determined by other government sectors, and 3) the scores from performance would be classified by the official performance. For the government officials who under probation period of official practice, they would be justified their performance as the general government officials. Results would be classified as pass or fail the appraisal (The Office of Civil Service 2008).

The situation of performance appraisal of secondary school teachers, under jurisdiction of the local administrative organization were conducted without obvious procedures to follow. Because of the schools were transferred to the local education department. Problems were occurred in not only performance appraisal but promotion of the Good Governance principles. As a result, the nepotism and group system needed to investigate (Wongprakan, 2008). Additionally, problems of performance appraisal were caused by the limitation in system design, application and implementation of performance appraisal in the organization. According to the survey, it found that the administrators spent insufficient time to consider the performance of staffs when they conduct appraisal. They were not trained systematically in using the appraisal form or interview techniques. In addition, they were not ready for accepting the mistakes in both of technique or outcome of the appraisal (Bretz, Milkovich, \& Read, 1992; Milkovich \& Wigdor 1991; Wyatt Company, 1989). Various problems of performance appraisal, for instance, the excessive appraisal score was caused by flaws in system design and its application on inappropriate context.

\subsection{Importance of the Problem}

Appraisal has its significant role on managing problems in educational administration. Appraisal of work practice reflects the efficiency and effectiveness of the organization. This is very important for the administrators to use appraisal system as a guideline for administrative approach. It is a major tool in developing relationship among various processes to improve different work units as well as organization itself. By giving an importance to the appraisal for improving work performance and staff development, it would result on the use their existed potentiality and the organization would accomplish its expected goal (The Office of Government Official, 2002). Educators and administrators should consider related factors affecting appraisal. Taylor et al. (1998) explained six factors of appraisal system in work practice as follows: 1) Specify goals and objectives, 2) Decide on means to be used, 3) Determine criteria of performance, 4) Set standards to be met on criteria, 5) Measurement of performance, 6) Comparison with standard. Likewise, Anthony, Perrewe, and Kacmar (2002)stated six kinds of factors in evaluative system in work appraisal as follows: 1)Job analysis, 2) Set performance standards, 3) Design a performance appraisal system, 4) Assess performance, 5) Performance review, and 6) Discuss a future plan of action. The guidelines for solving the problem caused by performance appraisal should focus on: 1) improving the measurement instrument, 2) training project, and 3) appraisal policy and process.

\subsection{Relevant Scholarships}

Different scholars have studied performance appraisal as a process and system. Thai teachers faced the problems in appraisal system from many areas of evaluation. Each period of appraisal, they had been evaluated on the basis of students performance, expected behaviors, teacher moral, and professional ethics by 60:10:10:20 ratio respectively. However, the students performances were not effectively related to the appraisal system. Teachers usually focused on preparing presentation materials such as lesson plans and student portfolios to evaluate in their performance appraisal. Less proportion of national standardized test score was used in teacher appraisal system. Most teachers focus their performance appraisal on presentation of teaching manual rather than actual teaching process and outcomes (Tungkitwanich \& Sasiwuttiwat, 2012). Feldman (1981) noted that performance appraisal is the dual-process system between evaluation and decision making. Also Brinkerhoff and Kanter (1979) showed that the context where performance appraisal being performed and used cannot be utilized alone. The context, as emphasized, is needs to take into the appraisal with full consideration and criticism. System of 
performance appraisal is the interaction between organizational context, information processing system, and behavioral system (Ilgen \& Feldman, 1983). Within the context and system of appraisal, the role of subordinate voice creates positive attitudes and satisfaction. The assessment of performance appraisal can be observed from instrument and non-instrumental voice (Korsgaard \& Roberson, 1995). Moreover, factors related to trustworthiness (ability, benevolence, and integrity) mediated the system of appraisal and trust in people (Mayer \& Davis, 1999).

Various studies and problems of performance appraisal were investigated. Excessive score of appraisal had been found as the problem of appraisal system since 1950 (Bernardin, Orban, \& Carlisle, 1981; Heron, 1956; Sharon \& Bartlett, 1969; Taylor \& Wherry, 1951). Although there was the improvement of training, project, appraisal policy, and process of performance appraisal for 40 years, those problems were still occurred until 2000s. It indicated that there were other problems in applying the performance appraisal in the organization or the problems were not being able to be solved. Several researchers in performance appraisal were not able to view the problems relevant to the points in appraisal. Some points might have been neglected (Wood \& Marshall, 1993). Influence from raters with poor skills in appraisal can be the substantial effect to the results which can predict the assumption in accountability (Kowalski \& Inks, 1990; Levy \& Williams, 2004).

\subsection{Purposes of the Study}

According to the above reasons, it was highly necessary to implement the effective teachers' appraisal system for schools under jurisdiction of the LAO. The researcher was interested in studying the current situation and problem of appraisal system in the secondary schools. Elements of appraisal design were based on the systematic approach, system development, evaluation in work practice, factors effecting performance, educational administration and management in the LAO, and the Good Governance principle. These related elements were used in developing the prototype of the appraisal system. These were considered as the guidelines for planning of professional development, following up the results, and performance appraisal of teachers. Three objectives of this research were: 1) to study current situation and problem in performance appraisal system, 2) to develop the model of the performance appraisal system to administered on the secondary school teachers under jurisdiction of the LAO, 3) to evaluate the initial application of performance appraisal system for its effectiveness and efficiency.

\section{Method}

Research and Development (R\&D) approach was employed for this study. Mixed methods research techniques were used in collecting data through quantitative and qualitative technique. The research was classified into three steps as the following:

\subsection{Step I: Study on Current Situation and Problem of Performance Appraisal System}

This step consisted of two methods: 1) In-depth interview from five experts regarding to the performance appraisal system. All of them hold the doctoral degrees and had work experience as administrators. Two of the experts were from the LAO responsible for strategic administration, two of them were from higher education institutes specializing in teacher training, and the last one was the school director under the LAO's jurisdiction. The instruments were the interview forms in performance appraisal system, the semi-structured interview, and the open-ended questions. All of the instruments were validated by five experts who were not related to five interviewees mentioned previously. Criteria in selecting validating experts were the doctoral degrees in educational administration or educational evaluation, academic ranking as assistant professor or higher, or work experience as the LAO school director. 2) Survey of current situation and problem from school directors, vice directors, division/department chairs. Total population was 10,756 samples from 231 LAO schools. Researcher selected the samples by the Stratified Random Sampling Method to have 1,911 samples size with 95\% confidence level. Schools in the Northeastern region were aimed to as a major selection because they represented the local context of the research project. The instrument using in this study was the questionnaire asking current situation and problem of performance appraisal system. The questionnaire was designed in the rating scale, and open-ended questions. In addition, there was a study visit trip to the school awarded for the Best Practice School Award from the LAO.

\subsection{Step II: Development in Performance Appraisal System}

It consisted of three sources of information for developing the performance appraisal system: 1) In-depth Interview from experts regarding to performance appraisal system. Criteria for selecting experts were based on education level (doctoral degrees preferred), academic ranking (assistant professor preferred), and work experience (at least 10 years on administration level in the LAO school or at least 5 years teaching in university 
level). 2) Survey of current information on the performance appraisal system of teachers. The areas of data included current condition and problems in performance appraisal. 3) Study visit to the Best Practice schools for using as guidelines in performance appraisal system. Four criteria of the Best Practice were: certifying Best Practice Award by the Office for National Education Standards and Quality Assessment (ONESQA), having high proficiency level of students, receiving regional level awarded in education excellence, and receiving public recognition. There were nine experts who responsible for investigating the propriety as well as feasibility of the model. They revised the tentative performance appraisal system of secondary school teachers and the handbook based on their opinion. The instrument used in this study was the questionnaire regarding to the propriety and feasibility in performance appraisal system. The questionnaire was constructed in the rating scale, and the open-ended questions.

\subsection{Step III: Evaluation in Application of Performance Appraisal System}

This step was aimed to apply the performance appraisal system on the participants on one of the LAO secondary schools by voluntary approach for 6 months, total participants were 26 persons. Participants represented one school director, one vice director, and 24 teachers. Purposive sampling method was used. It included the application of the system to the targeted schools. Research tools used in this step were the 5-level-Likert's scale questionnaire and open-ended questions to use in the focus group sessions. Evaluation of satisfaction was conducted after applying the modified appraisal system.

\section{Research Findings}

\subsection{Current Situation and Problem in the Performance Appraisal System}

Table 1. Current situation and problem in elements of performance appraisal

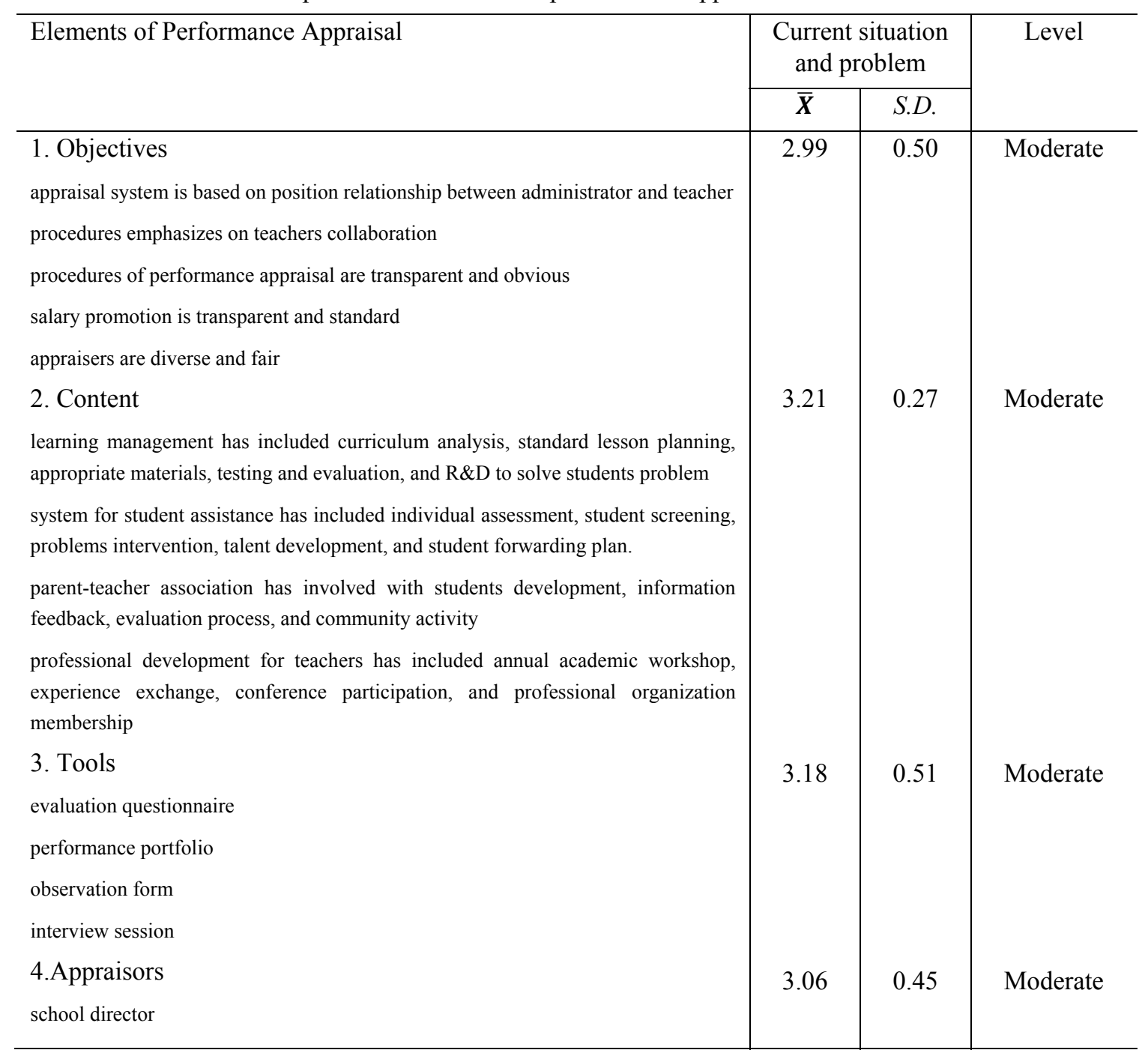




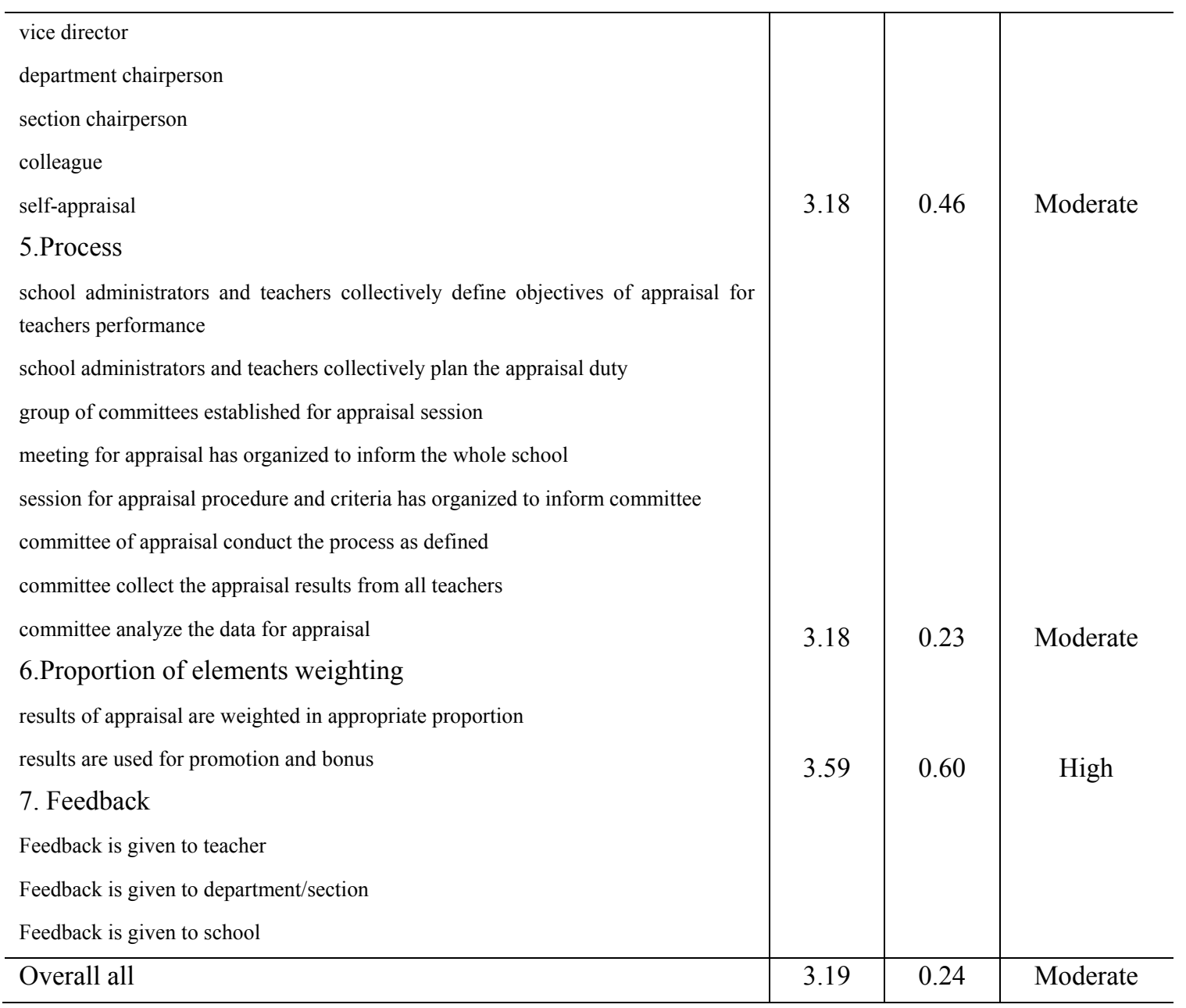

Note. Level of performance interpretation; 4.51-5.00 referred to Highest,3.51-4.50 referred to High, 2.51-3.50 referred to Moderate, 1.51-2.50 referred to Low, and 1.00-1.50 referred to Lowest.

It found that the situation in the performance appraisal system of the LAO's secondary school teachers in overall aspects of practice were in "Moderate" level. Except the Feedback aspects, the practices were in "High" level. Problem in the performance appraisal system in overall aspect was in "High" level. Considering each factor, three problems were in "High" level were the objective of work practice evaluation, the process of performance appraisal, and the content in performance appraisal.

\subsection{The Development in the Performance Appraisal System}

Four major elementsrelated to input were1) the objective of performance appraisal, 2) the content of performance appraisal, 3) the tools of performance appraisal, and 4) performance appraisal evaluation. The process related factors consisted of three sub-factors which were: 1) planning, 2) action, 3) evaluations and report. The output factors consisted of six factors: 1) Clear objective, 2) Covered and accountable content, 3) Appropriate and reliable instrument, 4) Correct usage and accurate tools, 5) Acceptable results, and 6) Satisfaction of teachers. The model of performance appraisal system is shown in Figure 1: 


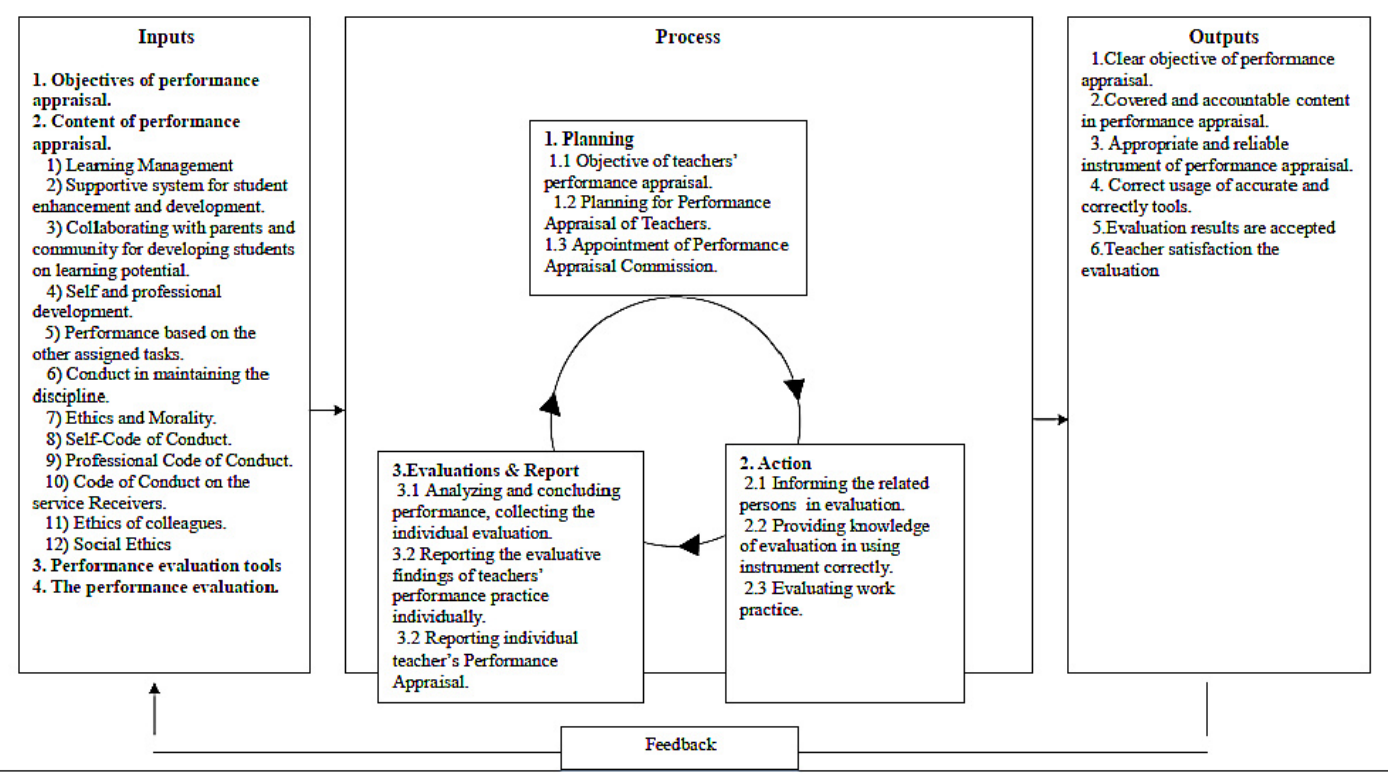

Figure 1. The performance appraisal system of secondary school teachers under the local administrative organization

\subsection{The Process for Application in the Performance Appraisal System}

\section{Step I: Planning}

This was the preparation stage for developing the awareness and significance by following these implementations:

- The administrators and teachers collaborated in determining the objective, and analyzing the current situation and problem in performance appraisal.

- They collaborated determined the designing of the performance appraisal.

- The committee was appointed for implementing the performance appraisal.

- They were included the school director, vice directors, and division/department chairs.

- The workshop was held for organizing activities relevant to the objective of performance appraisal.

- The action plan of performance appraisal, revision, improving, and recommendations.

Step II: Action

This step was based on the action plan in performance appraisal system. The implementations were as follows:

- The administrators held the conference for informing and developing the awareness in performance appraisal to the teachers.

- The evaluators provided instructions to the administers in order to implement the instruments correctly.

- The detail of content in practice evaluation for performance appraisal was determined.

- The evaluators in performance appraisal (the director, vice directors, department/division chairs, and teachers) determine the duration of evaluation.

- The evaluators of work performance had different tasks; for instance, teachers' performances were evaluated by the school director, vice-directors, department/division chairs, and their co-workers. Also, they did self-evaluation.

- Evaluation was informed to the teachers for their promotion and rewards.

Step III: Evaluation and Reporting

The process of evaluations and reporting were implemented as follows:

- The evaluators investigated, supervised, followed up the evaluation findings in performance appraisal of the teachers based on criterion and conducted timely as stated in the schedule.The appraisers investigated and 
reported the evaluative findings in September.

- The committee of evaluation worked with teachers to collect individual appraisal result.

- The results of teachers' performance appraisal were concluded to inform administrators for decision making in promotion.

- The information obtained from previous round of performance appraisal was used as supplementary information for reviewing the performance evaluation in the current year. This was used to plan for development of the performance appraisal system of secondary school teachers in the following year.

The evaluation of application of the performance appraisal system found that the system application was practiced the "Highest" level at the overall. While the satisfaction of the performance appraisal system in overall and each aspect was in "High" level.

\section{Discussions}

\section{1.The Current Situation and Problem in Performance Appraisal}

Results in overall and each sub-aspect, the practices were in "Moderate" level, whereas the feedback was in "High" level. Overall current problem in performance appraisal system was in "High" level. After considering each factor, the problems of three factors were in "High" level including: 1) the objective of performance appraisal, 2) the process of performance appraisal, and 3) the content of performance appraisal respectively. The cause might be due to the administrators had insufficient of time in performance appraisal and lacking of the Good Governance principles. Although the implementation was conducted by the committees who followed the steps, the focus on evaluation criterion was still based on the indicators. These had vague evaluation. Appraisal was conducted by to authoritative order rather than participation. As a result, it affected the teachers' morale in working. Consequently, supportive system and nepotism were occurred. More concreted evaluation system was needed.

Moreover, the evaluators administered appraisal by the instrument incorrectly. It was supported by Bretz, Milkovich, and Read (1992) who stated some problems of performance appraisal that caused from system design, application or implementation of performance appraisal in organization. There was a survey found that the administrators spent very little amount of time in evaluating their staffs, they were not trained systematically in administering the evaluative forms or interview techniques in evaluation. In addition, they were not ready for accepting the mistakes in evaluative techniques or outcomes. It was congruent with Bernardin, Orban, and Carlisle (1981) that the different problems in performance appraisal such as the high score of evaluation was caused by limitation in designing and applying the system which were not studied appropriately. Therefore, the guidelines for solving the problem caused by work practice evaluation, were presented by improving the measurement instrument, training program, policy as well as process of work performance appraisal. It was supported by the findings of the study in Thailand. Roojanaseri's (2002) study found that the present problem of staff management in local organization related to professional progress could be the result of power centralization of staff management. Authority was depended on the administrators of the LAO.

Ethical principle was another factor to emphasize because it could affect the advancement of staffs in local organization. As a result, weak of ethical principle had influential effect on salary raise and expansion of staff employment. Then the government officials or staffs of local organization could not have progress from the appraisal of the system. It was congruent with the Office of Local Staff Management Committee's study (2003) which found that there were problems of salary raise resulted from the administration difference between schools under the Local Administration Organization and the Ministry of Education. It was also relevant to Scheerens (2000) stated that the evaluation was a necessary part of their school work, although it was true that the efficiency of recent evaluative system, there were a lot needed to be improved.

\subsection{The Performance Appraisal System}

The performance appraisal system consisted of four major factors of Input which included: 1) the objective of performance appraisal, 2) the content of performance appraisal, 3) the instrument of performance appraisal, and 4) the evaluators of the performance. Factor for the Process, consisted of three sub-factors: 1) planning, 2) action, 3) conclusions and report. The Output consisted of two factors including: 1) the reliability of performance appraisal, 2) the teachers' satisfaction in performance appraisal. The Feedback consisted of two factors including: 1) the teacher performance feedback, and 2) the appraisal output for school. The foundation of this study was similar to Dressler's (2000) notion in factors of performance evaluation process. The factors are: 1) the objective of appraisal framework, 2) the steps of performance appraisal, and 3) the evaluation of findings and feedback. 
It was also congruent with Rupan's (2003) study consisted of four major structures of appraisal system: Input, Process, Output, and Feedback. While Rupan's Input factors consisted of the objective of evaluation, indicators, criterion of evaluation, instrumental document, content of evaluation, evaluators, and those who were evaluated. Also sharing similarity, Process factor for performance appraisal consisted of the planning for evaluation, work practice, construction and development of instrument, collection of information of work performance, data analysis and evaluation of performance appraisal by comparing with the specified criterion. The Output factor was evaluated by the recorded form. This was the conclusions in work practice evaluation of Basic Education Commission. The Feedback factor consisted of the information released from the Basic Education Commission and the Office of Educational Service Area to be included for performance appraisal.

System development procedures were the influential factors of performance appraisal. Intrararoong (2009) found that there were four steps of system implementation. There were stated that: Step 1)the appointment of committee to investigate the evaluation findings in work practice, Step 2)the measurement of evaluation performed by using the intended instrument, Step 3) the report of evaluation system by the performance evaluation committee, and Step 4) the analysis of system by using data analysis and data interpretation. Our results were also supported by Hankla's (2002) including five factors as follows: 1) Input factors: the objective of auditing and following up, the principle of auditing and following up, the staffs being responsible in auditing and following up, and the instrument using in following up system, 2) Process factors: included the following steps: planning for auditing and following up, implementing in auditing and following up, concluding in the auditing and following up, evaluating the effectiveness in auditing and following up, reviewing by the administrative division, and acting for improving and following up in auditing and following up, 3) Output factors: involved report procedures in auditing and following up the quality, 4) Feedback factors: included the information obtaining from evaluating the effectiveness in auditing and following up, reviewing by the administrative division, and the practice of correcting and following up in auditing and following up, 5) Environmental and Situational factors: the management of the situation outside of the environment. Similarly, Prommapan's (2004) study found that the model and guidelines for establishing the system of evaluation included the resources using for Input, Process, and Outcome. The guidelines in evaluation consisted of five steps: 1) the development of awareness, 2) the readiness preparation, 3) the planning for self-assessment, 4) the report writing and disseminating, and 5) the application of evaluation findings.

\subsection{The Findings in Application of Developed Performance Appraisal System}

The application in the performance appraisal system for the development of work implementation system, in overall, was in "the Highest" level. This finding was supported by Intrararoong's (2009) study found that every factor of the system was appropriate in "High" level. Furthermore, the evaluation findings of evaluation in standard based on standard criterion of system evaluation in Accuracy, Feasibility, Propriety, and Utility was in "High" level in every aspect. In addition, Rupan's (2003) study also supported our findings. It found that the factors in every item of the system, were appropriate in "High" level. Besides, the findings of evaluation were based on standard criterion of evaluation in Utility, Feasibility, Propriety, and Accuracy; the findings were in "High" level in every aspect. Tipayachan's (2004) study found that the development of evaluation model in work practice had the relationship of seven factors: the Feasibility to be used in real situation, the Accuracy as the truth, the Propriety which was appropriate with evaluation policy in administrative policy of Rajabhat Institute. Moreover, in other countries besides Thailand, Ovando and Ramirez's (2007) found that the integration of evaluation process could cover holistic appraisal. School used the teaching evaluation to support the appraisal system. This worked as a final instrument in providing advice and to audit teacher performance. Holistic teaching evaluation provided opportunity in training so that the teachers would establish clear expectation.

The satisfaction on the application in performance appraisal system in overall, it was in "Highest" level. Considering each aspect, found that it was in "High" Level in every aspect. It was supported by Intrararoong's (2009) and Rupan (2003). It found that the application of performance appraisal system was in "High" level. In addition, the findings were standardized based on criteria of system evaluation in Accuracy, Feasibility, Propriety, and Utility. Each criterion was in "High" Level.

\section{Conclusions and Suggestions}

In conclusion, the research on the LAO schools appraisal system reported three main aspects in current situation, performance of the system, and the application as follows:

\subsection{The Current Situation of Performance Appraisal System}

The overall practices were in "Moderate" level except the Feedback was in "High" level. For the overall problem of performance was in "High" level. Considering each factor, we found that the problems were related to: 1) the 
objective of performance appraisal, 2) the process of performance appraisal, and 3) the content of performance appraisal.

\subsection{The Performance Appraisal System}

It was consisted of four major factors of the Input which included: 1) the objective of performance appraisal, 2) the content of performance appraisal, 3) the instrument of performance appraisal, and 4) the evaluators of performance appraisal. The Process consisted of three sub-systems. Each sub-system was the working unit of performance appraisal system including: 1) Planning, 2) Action, and 3) Evaluation and Report, and 4) Feedback.

\subsection{The Application in the Developed Performance Appraisal System}

It found that: 1) Overall performance appraisal system was in "Highest" level, 2) Overall satisfaction in application of performance appraisal system was in "High" level. Considering each aspect, it found that every aspect was in "High" level.

Suggestions for the schools to adopt this research for implementation is emphasized on the vision that concerned on effective procedures of appraisal as well as having complete manual of appraisal system to be consult. Teachers were also needed to be encouraged on conducting self-appraisal. Feedback can be used as the development for correcting weakness and supporting strength. The LAO has to include the appraisal system with teachers' responsibilities in regular basis.

In summary, performance appraisal is a virtal tool in developing schools under local administration organization, especially in Thailand. The current situation is highly depending on objective of the appraisal system which the process of how schools conduct the procedures according to each content of the objectives. Moreover, systematic appraisal is what future researcher in appraisal study should emphasize (Bretz, Milkovich, \& Read, 1992). In addition to Rupan (2003), one of the suggested approaches is PAEF cycle which referred to Planning comprehensively, Action promptly, Evaluation throughoutly, and Feedback retrospectively.

\section{References}

Anthony, W. P., Perrewe, P. L., \& Kacmar, K. M. (2002). Human Resource Management, A Strategic Approach (4th ed.). Ohio: South-Western.

Bernardin, H. J., Orban, J., \& Carlisle, J. (1981). Performance ratings as a function of trust in appraisal and rater individual differences. Proceedings of the $41^{s t}$ annual meeting of the Academy of Management (pp. 311-315).

Bretz, R. D., Milkovich, G. T., \& Read, W. (1992). The current state of performance appraisal research and practice: Concerns, directions, and implications. Journal of Management, 18(2), 321-352. http://dx.doi.org/10.1177/014920639201800206.

Brinkerhoff, D. W., \& Kanter, R. M. (1979).Appraising the performance of performance appraisal. Sloan Management Review, 21(3), 3-16.

Feldman, J. M. (1981). Beyond attribution theory: Cognitive processes in performance appraisal. Journal of Applied Psychology, 66(2), 127. http://dx.doi.org/10.1037/0021-9010.66.2.127

Hankla, C. (2002). The Development of Internal Quality Audit System of Rajabhat Institute (Unpublished doctoral dissertation). Doctor of Philosophy in Education, Graduate School of Chulalongkorn University, Bangkok, Thailand.

Heron, A. (1956). The effects of real-life motivation on questionnaire response. Journal of Applied Psychology, 40, 65-68. http://dx.doi.org/10.1037/h0047260

Ilgen, D. R., \& Feldman, J. M. (1983). Performance appraisal: A process focus. Research in Organizational Behavior, 5, 141-197.

Institute of Civil Service Development, Office of the Civil Service Commission. (1997). Staff Management. Bangkok: The Office of Government Official.

Intrararoong, C. (2009). The Development of Performance Appraisal System of Governmental Teachers (Unpublished doctoral dissertation). Doctor of Philosophy in Educational Administration, Graduate School of Siam University, Bangkok, Thailand.

Klimoski, R., \& Inks, L. (1990). Accountability forces in performance appraisal. Organizational Behavior and Human Decision Processes, 45(2), 194-208. http://dx.doi.org/10.1016/0749-5978(90)90011-w

Korsgaard, M. A., \& Roberson, L. (1995). Procedural justice in performance evaluation: The role of instrumental 
and non-instrumental voice in performance appraisal discussions. Journal of Management, 21(4), 657-669. http://dx.doi.org/10.1177/014920639502100404

Levy, P. E., \& Williams, J. R. (2004). The social context of performance appraisal: A review and framework for the future. Journal of Management, 30(6), 881-905. http://dx.doi.org/10.1016/j.jm.2004.06.005.

Maharatsakul, P. (2002). New Approach of Human Resource Management (3rd ed.). Bangkok: Z-Four Printing.

Mayer, R. C., \& Davis, J. H. (1999). The effect of the performance appraisal system on trust for management: A $\begin{array}{llllll}\text { field quasi-experiment. Journal of Applied Psychology, } & \text { 84(1), } & 123 .\end{array}$ http://dx.doi.org/10.1037/0021-9010.84.1.123

Milkovich, G. T., \& Wigdor, A. K. (1991). Pay for performance. Evaluating performance appraisal and merit pay. Washington, D.C: National Academy Press.

Noe, R. A., Colquitt, J. A., Simmering, M. J., \& Alvarez, S. A. (2003). Developing Intellectual and Social Capital. The Organizational Frontiers Series, 209. http://dx.doi.org/10.1037/0021-9010.88.5.954

Office of Civil Service. (2008). Manual of Performance Appraisal in Government Sectors: The Overall System of Administration and Appraisal of Practice. Bangkok, P. A. Living.

Office of Local Staff Management Standard Commission. (2002). Problem in Staff Management of Sub-district Administrative Organization. Local Administrative Development College, King Prajadhipok's Institute.

Ovando, M. N., \& Ramirez, A. Jr. (2007). Principals' instructional leadership within a teacher performance appraisal system: Enhancing students' academic success. Journal of Personnel Evaluation in Education, 20(1-2), 85-110. http://dx.doi.org/10.1007/s11092-007-9048-1

Peck, R. D. (1984). Entrepreneurship as a Significant Factor in Successful Adaptation. The Journal of Higher Education, 269-285. http://dx.doi.org/10.2307/1981188

Prommapan, B. et al. (2004). The Report of HR Index development for Local Government Appraisal. Bangkok: Sukotaisharmatirach Open University Press.

Roojanaseri, P. et. al. (2002). Educational Document on the Improvement of Local Administration. Bangkok: Thai Rak Thai Party.

Rupan, P. (2003). A Development of the Performance Appraisal System of Basic Education Institutes Committee (Unpublished doctoral dissertation). Doctor of Philosophy in Educational Administration, Graduate School of Chulalongkorn University, Bangkok, Thailand.

Scheerens, J. (2000). Improving School Effectiveness. UNESCO International Institute for Educational Planning.

Sharon, A., \& Bartlett, C. (1969). Effect of Instructional Conditions in Producing Leniency on Two Types of Rating Scales. Personnel Psychology, 22, 252-263. http://dx.doi.org/10.1111/j.1744-6570.1969.tb00330.x

Taylor, E., \& Wherry, R. (1951). A Study of Leniency of Two Rating Systems. Personnel Psychology, 4, 39-47. http://dx.doi.org/10.1111/j.1744-6570.1951.tb01459.x

Taylor, M. S., Masterson, S. S., Renard, M. K., \& Tracy, K. B. (1998). Managers' Reactions to Procedurally Performance Management Systems. Academy of Management Journal, 41(5), 568-579. http://dx.doi.org/10.2307/256943

Tipayachan, A. (2004). Development of Evaluative Model in Work Practice of Rajabhat Instructors (Unpublished doctoral dissertation). Doctor of Philosophy in Education, Graduate School of Naresuan University, Phitsanulok, Thailand.

Tungkitwanich, S., \& Sasiwuttiwat, S. (2012). Failure of Thailand's Educational Appraisal. Retrieved from http://www.prachatai.com/journal/2012/02/39252

Wongprakan, K. (2009). Problem of Staff Management in Roi-ed Provincial Administrative Organization (Unpublished doctoral independent study report). Master of Education, Graduate School of Siam University, Bangkok, Thailand.

Wood, R., \& Marshall, V. (1993). Performance Appraisal, Practice, Problems and Issues. Organisation for Economic Co-operation and Development.

Wyatt Company. (1989). Results of the 1989 Wyatt survey: Getting your hands around Performance management. The Wyatt Communicator, Fourth Quarter, Washington, D.C. 


\section{Copyrights}

Copyright for this article is retained by the author(s), with first publication rights granted to the journal.

This is an open-access article distributed under the terms and conditions of the Creative Commons Attribution license (http://creativecommons.org/licenses/by/3.0/). 